University of Nebraska - Lincoln

DigitalCommons@University of Nebraska - Lincoln

Nebraska Game and Parks Commission -- Staff

Research Publications

Nebraska Game and Parks Commission

January 1974

\title{
Self-sustaining Rainbow Trout (Salmo gairdneri) Population in McConaughy Reservoir, Nebraska
}

Rodney C. Van Velson

Nebraska Game and Parks Commission

Follow this and additional works at: https://digitalcommons.unl.edu/nebgamestaff

Part of the Environmental Sciences Commons

Van Velson, Rodney C., "Self-sustaining Rainbow Trout (Salmo gairdneri) Population in McConaughy Reservoir, Nebraska" (1974). Nebraska Game and Parks Commission -- Staff Research Publications. 30. https://digitalcommons.unl.edu/nebgamestaff/30

This Article is brought to you for free and open access by the Nebraska Game and Parks Commission at DigitalCommons@University of Nebraska - Lincoln. It has been accepted for inclusion in Nebraska Game and Parks Commission -- Staff Research Publications by an authorized administrator of DigitalCommons@University of Nebraska - Lincoln. 
Self-sustaining Rainbow Trout (Salmo gairdneri) Population in MeConaughy Reservoir, Nebraska

Rodney C. Van Velson

Made in United States of America

Reprinted from Transactions of the American Fisheries Society

Vol. 103, No. 1, January 1974

pp. 59-64 


\title{
Self-sustaining Rainbow Trout (Salmo gairdneri) Population in McConaughy Reservoir, Nebraska
}

\author{
Rodney C. Van Velson \\ Nebraska Game and Parks Commission \\ Alliance, Nebraska 69301
}

\begin{abstract}
A self-sustaining rainbow trout population has developed in the North Platte River drainage. This population inhabits McConaughy Reservoir and reproduces successfully in tributary streams of the North Platte River located approximately 113 to $145 \mathrm{~km}$ above the reservoir. Fall and spring spawning populations migrate from the reservoir.

Scale analysis indicated $92 \%$ of the juveniles had spent $1 \mathrm{yr}$ and $8 \%$ had spent 2 yr in the stream before the spring migration to the reservoir as $175-250 \mathrm{~mm}$ smolts. In the 1965-1969 spawning populations 13 life history categories were present. The spawning runs were composed of $76 \%$ maiden spawners, $22 \%$ second-year spawners and $2 \%$ third-year spawners. The sex ratio of the spawning runs ranged between $2.0-2.2$ females per male.

The rainbow trout population is subjected to a variety of conditions in tributary streams of the North Platte during summer including flooding, irrigation return water and high water temperatures. However, spawning rainbow trout utilize these groundwater streams from November through April. In addition the coldwater habitat in the reservoir is restricted throughout the summer, especially during August.

The established rainbow trout population survived better in this environment than hatchery rainbow trout.
\end{abstract}

McConaughy Reservoir provides an important regional sport fishery. The self-sustaining rainbow trout (Salmo gairdneri) fishery in the reservoir is unique for the Great Plains area. Rainbow trout in McConaughy Reservoir sustain themselves through natural reproduction in tributary streams of the North Platte River approximately 113 to $145 \mathrm{~km}$ above the reservoir. In addition to the rainbow trout population this reservoir also provides an excellent warmwater fishery and meets the requirements of a "two-story" reservoir as described by Kirkland and Bowling (1966). The ecology and fishery management of the reservoir was described by McCarraher, Madsen and Thomas (1971).

The popularity of rainbow trout fishing in McConaughy Reservoir increased rapidly during the early sixties. To maintain this quality reservoir fishery and the popular rainbow trout stream fishery which exists in the spawning streams, basic life history data had to be collected and a management plan developed. This paper describes the self-sustaining rainbow trout population and the environmental conditions under which it exists.

\section{STUDY AREA AND METHODS}

McConaughy Reservoir, Keith County, Nebraska is located on the lower North Platte
River approximately $193 \mathrm{~km}$ downstream from the Nebraska-Wyoming state line (Fig. I). Created in 1941 by the construction of Kingsley Dam, the 14,000-ha irrigation storage reservoir is the largest body of water in Nebraska. The maximum depth of this reservoir is $43 \mathrm{~m}$.

Some streams in the upper North Platte River drainage in western Nebraska support self-sustaining rainbow trout populations (Fig. 1). Nine Mile Creek (mean flow 124, cfs 1963-1968) contains the best spawning habitat and supports the largest run of rainbow trout from McConaughy Reservoir. Red Willow Creek and Tub Springs are the other major spawning streams.

My field data were collected between 1965 and 1969. Fyke nets, electrofishing, and an electrical weir were used to sample the rainbow trout population. Rainbow trout $305 \mathrm{~mm}$ total length and over were classified as adults. Individuals under $305 \mathrm{~mm}$ were recorded as juveniles.

Adult rainbow trout were sampled in the spawning streams and the reservoir. The 1965-1966 rainbow trout runs from McConaughy Reservoir were monitored by stream sampling. The 1967-1969 spawning runs were sampled at the Lewellen electrical weir and fish trap in the North Platte River im- 


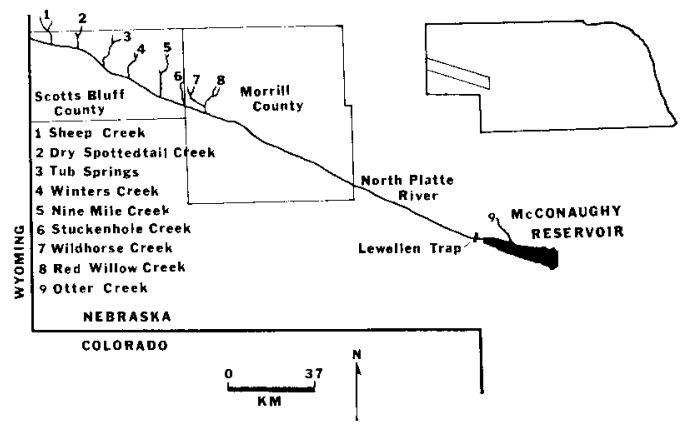

Figure 1.-McConaughy Reservoir streams which support self-sustaining rainbow trout populations in the Upper North Platte River drainage, Nebraska.

mediately above the reservoir where it was possible to separate the fall and spring spawning populations (Fig. 1). The operation and description of the electrical weir and fish trap was described by Madsen (1973). Age and growth data were collected randomly when sample sizes were large. Sexual maturity of the adult spawners was classified according to gonad condition. Rainbow trout were recorded as sexually mature when the sex products were visible after gentle pressure was applied along the underside of the body. Age determinations were made by two independent scale interpretations. Scale interpretation was used to determine migration patterns and to classify the life history categories. Designations for life history categories were modified from Shapovalvo and Taft (1954) and Hartman (1959).
Juvenile rainbow trout were captured throughout the drainage. Those of about $102-203 \mathrm{~mm}$ were finclipped to determine migration patterns and to verify age determinations. Marked rainbow trout were recaptured in the reservoir, at the Lewellen trap, and in the spawning streams when they returned to spawn.

I monitored the trout habitat in McConaughy Reservoir by dissolved oxygen and temperature data during the summers of 1969-1970 with the oxygen and temperature criteria described by Kirkland and Bowling (1966). Trout supporting water was defined as 21.1 $\mathrm{C}$ or colder, containing at least 3.0 $\mathrm{mg} /$ liter oxygen. Oxygen and temperature data were collected bimonthly during the midday period at three permanent sampling stations during June through September.

\section{RESULTS}

\section{Life History}

Thirteen life history categories were identified from fish in the 1965-1969 spawning runs (Table 1). The predominant life history category (1/2) described $58 \%$ of the spawning population; these trout were spawning for the first time after spending one growing season in the stream as juveniles and two growing seasons in the reservoir. Spawning runs were comprised of $67 \%$ 3-year-old, $24 \%$ 4year-old, $8 \%$ 2-year-old and $1 \% \quad 5$-year-old rainbow trout.

TABLE 1.- Life history categories represented in the 1965-1969 spawning runs of McConaughy Reservoir rainbow trout

\begin{tabular}{|c|c|c|c|c|c|c|c|c|c|}
\hline \multirow[b]{2}{*}{$\begin{array}{l}\text { Life history } \\
\text { category }\end{array}$} & \multirow[b]{2}{*}{$\begin{array}{c}\text { Spawner } \\
\text { classification }\end{array}$} & \multicolumn{6}{|c|}{ 1965-1969 Spawning runs } & \multicolumn{2}{|c|}{ Totals } \\
\hline & & 1965 & 1966 & 1967 & $\begin{array}{r}\text { Fall } \\
1968\end{array}$ & $\begin{array}{c}\text { Spring } \\
1969\end{array}$ & $\begin{array}{l}\text { Fall } \\
1969\end{array}$ & Number & Percent \\
\hline $1 / 1^{a}$ & Maiden & 4 & 18 & 32 & 4 & 1 & 14 & 73 & 8.4 \\
\hline $1 / 1.1 \mathrm{~S}$ & 2nd year & 33 & 19 & 2 & 2 & 2 & 7 & 65 & 7.5 \\
\hline $1 / 1.2 \mathrm{~S}$ & 3 rd year & 6 & 4 & 2 & & & 2 & 14 & 1.6 \\
\hline $1 / 2$ & Maiden & 119 & 73 & 68 & 86 & 64 & 98 & 508 & 58.3 \\
\hline $1 / 2.1 \mathrm{~S}$ & 2nd year & 16 & 29 & 7 & 15 & 12 & 35 & 114 & 13.1 \\
\hline $1 / 2.2 \mathrm{~S}$ & 3rd year & - & $=$ & 4 & - & 1 & 1 & $\stackrel{2}{7}$ & .2 \\
\hline $1 / 3$ & Maiden & 4 & 5 & 4 & 4 & 2 & 8 & 27 & 3.1 \\
\hline $1 / 3.1 \mathrm{~S}$ & 2nd year & 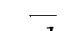 & 1 & - & 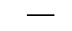 & 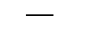 & $=$ & 1 & .1 \\
\hline $2 / 1$ & Maiden & 1 & $=$ & 2 & - & — & 7 & 10 & 1.1 \\
\hline $2 / 1.1 S$ & 2nd year & 9 & 1 & I & - & - & 1 & 12 & 1.4 \\
\hline $2 / 2$ & Maiden & 14 & 4 & 6 & 7 & 2 & 7 & 40 & 4.6 \\
\hline $2 / 2.1 \mathrm{~S}$ & Ind year & 1 & - & - & - & I & 2 & 4 & .5 \\
\hline $2 / 3$ & Maiden & $2 \overline{07}$ & $\overrightarrow{154}$ & $\overline{124}$ & $1 \overline{18}$ & $\overline{85}$ & $\begin{array}{r}1 \\
183\end{array}$ & $\begin{array}{r}1 \\
871\end{array}$ & 100.0 \\
\hline & & & & & & & & & \\
\hline
\end{tabular}

"The number of years of stream life are to the left of /. The sum of the numbers to the right of the / are the years spent in the reservoir. The number and the letter $S$ to the right of the period indicates the number previously completed spawning runs not including the present one. 
The 1965-1969 spawning populations contained $76 \%$ maiden spawners, $22 \%$ second year spawners and $2 \%$ third year spawners (Table 1). All the third year spawners had been 1-year-old smolts. Analysis of scales from spawners indicated $20 \%$ of the fish had spent only one growing season, $77 \%$ spent two growing seasons, and $3 \%$ had spent three growing seasons in the reservoir before maturation and entering the first spawning migration. At the Lewellen trap none of the fall run, but $54 \%$ of the spring run, was sexually mature when sampled. In the 19651969 spawning runs $92 \%$ of the rainbow trout had been 1-year-old smolts and $8 \%$ had been 2-year-old smolts before downstream migration to the reservoir. The sex ratio during the three fall spawning runs (1967-1969) and the 1969 spring run averaged 2.2 females per male (range 2.0-2.2)

Growth data indicated rainbow trout 2 years old which spent $\mathrm{I}$ yr in the reservoir averaged $394 \mathrm{~mm}$ and weighed $0.7 \mathrm{~kg}$ (Table 2 ). After $2 \mathrm{yr}$ in the reservoir the fish averaged $526 \mathrm{~mm}$ long and $1.7 \mathrm{~kg}$ in weight. After 3 and $4 \mathrm{yr}$ they averaged $571 \mathrm{~mm}$ and $2.2 \mathrm{~kg}$ and $559 \mathrm{~mm}$ and $1.6 \mathrm{~kg}$, respectively. Growth in the reservoir between the first and second spawning runs averaged $94 \mathrm{~mm}$, excluding the small sample size data (Table 3 ).

Anglers voluntarily returned $22 \%$ of the tags affixed to 448 rainbow trout during the 1967-1969 spawning runs. Of this $22 \%$ return the stream fishery accounted for $65 \%$ and the lake fishery $35 \%$.

\section{Migration}

Juvenile rainbow of $175-250 \mathrm{~mm}$ migrated to the reservoir during spring. Marked ju-
TABLE 2.-Mean lengths and weights of rainbow trout life history categories represented in the 1965-1969 spawning runs

\begin{tabular}{lcccc}
\hline $\begin{array}{c}\text { Life history } \\
\text { category }\end{array}$ & $\begin{array}{c}\text { Mean total } \\
\text { length } \\
(\mathrm{mm})\end{array}$ & $\begin{array}{c}\text { Sample } \\
\text { size }\end{array}$ & $\begin{array}{c}\text { Mean } \\
\text { weight } \\
\mathrm{kg}\end{array}$ & $\begin{array}{c}\text { Sample } \\
\text { size }\end{array}$ \\
\hline $1 / 1$ & 391 & 73 & .7 & 61 \\
$1 / 1.1 \mathrm{~S}$ & 521 & 65 & 1.6 & 61 \\
$1 / 1.2 \mathrm{~S}$ & 553 & $\mathbf{1 4}$ & 1.8 & 14 \\
$1 / 2$ & 528 & 508 & 1.7 & 348 \\
$1 / 2.1 \mathrm{~S}$ & 569 & 114 & 2.2 & 87 \\
$1 / 2.2 \mathrm{~S}$ & 564 & 27 & $\mathbf{8 . 4}$ & $\mathbf{2 1}$ \\
$1 / 3$ & 584 & 27 & 1.4 & 1 \\
$1 / 3.1 \mathrm{~S}$ & 546 & 1 & 1.6 & 9 \\
$2 / 1$ & 406 & 10 & .7 & 1.5 \\
$2 / 1.1 \mathrm{1S}$ & 518 & 12 & 1.5 & 30 \\
$2 / 2$ & 508 & 40 & 1.5 & 3 \\
$2 / 2.1 \mathrm{~S}$ & 587 & 4 & 2.4 & $\mathbf{1}$ \\
$\mathbf{2} / 3$ & 630 & 1 & 3.1 & \\
\hline
\end{tabular}

veniles averaged $236 \mathrm{~mm}$ when captured in the reservoir during April and May in 1967 and 1968. Just prior to downstream migration from the spawning streams, juveniles lost their parr marks and turned from light gray to bright silvery white. Also the tips of the dorsal and the caudal fin turned nearly black and the body became more streamlined. This population apparently goes through a smolt stage similar to that of rainbow trout populations in larger inland lakes, as described by Greeley (1933), Rayner (194I) and Hartman (1957).

There were two distinct rainbow trout spawning migrations from McConaughy Res. ervoir. The larger fall run began during September and continued until late November while the smaller spring run extended from March into April (Table 4). Spawning of rainbow trout from McConaughy Reservoir can be observed in streams from November through April. December, the most active spawning period, represents the peak spawning period of fall run trout. March is the

TABLE 3.-Growth of the life history categories in McConaughy Reservoir

\begin{tabular}{|c|c|c|c|c|c|c|}
\hline $\begin{array}{l}\text { Years of } \\
\text { stream } \\
\text { life }\end{array}$ & $\begin{array}{l}\text { Years of } \\
\text { reservoir } \\
\text { life before } \\
\text { entering } \\
\text { spawning } \\
\text { runs }\end{array}$ & $\begin{array}{l}\text { First spawning run, } \\
\text { mean length } \\
(\mathrm{mm})\end{array}$ & $\begin{array}{l}\text { Growth } \\
\text { difference } \\
(\mathrm{mm})\end{array}$ & $\begin{array}{l}\text { Second spawning run, } \\
\text { mean length } \\
(\mathrm{mm})\end{array}$ & $\begin{array}{l}\text { Growth } \\
\text { difference } \\
(\mathrm{mm})\end{array}$ & $\begin{array}{c}\text { Third spawning run, } \\
\text { mean length } \\
(\mathrm{mm})\end{array}$ \\
\hline $\begin{array}{l}1 \\
1 \\
1 \\
2 \\
2 \\
2\end{array}$ & $\begin{array}{l}1 \\
2 \\
3 \\
1 \\
2 \\
3\end{array}$ & $\begin{array}{ll}391 & (1 / 1)^{a} \\
528 & (1 / 2)^{2} \\
584 & (1 / 3) \\
406 & (2 / 1) \\
508 & (2 / 2) \\
630^{b} & (2 / 3)\end{array}$ & $\begin{array}{r}130 \\
41 \\
-38 \\
112 \\
79 \\
\end{array}$ & $\begin{array}{ll}521 & (1 / 1.1 S) \\
569 & (1 / 2.1 S) \\
546^{\mathrm{b}} & (1 / 3.1 S) \\
518 & (2 / 1.1 S) \\
587^{\mathrm{b}} & (2 / 2.1 S) \\
- & \end{array}$ & $\begin{array}{l}32 \\
-5 \\
- \\
- \\
-\end{array}$ & $\begin{array}{ll}553 & (1 / 1.2 \mathrm{~S}) \\
564^{\mathrm{b}} & (1 / 2.2 \mathrm{~S}) \\
- & \\
- & \\
- & \end{array}$ \\
\hline
\end{tabular}

a Life history categories.

b Sample size less than 10 individuals. 
TABLE 4.-Adult rainbow trout sampled at the Lewellen trap, 1967-1970

\begin{tabular}{|c|c|c|c|}
\hline \multicolumn{2}{|l|}{ Fall run } & \multicolumn{2}{|l|}{ Spring run } \\
\hline Operation dates & $\begin{array}{l}\text { Number } \\
\text { captured }\end{array}$ & Operation dates & $\begin{array}{l}\text { Number } \\
\text { captured }\end{array}$ \\
\hline $\begin{array}{l}4 \text { October- } \\
27 \text { November } 1967\end{array}$ & $100^{a}$ & $\begin{array}{l}8 \text { March- } \\
1 \text { April } 1968\end{array}$ & $21^{b}$ \\
\hline $\begin{array}{l}18 \text { September- } \\
15 \text { November } 1968\end{array}$ & 665 & $\begin{array}{l}31 \text { March- } \\
21 \text { April } 1969\end{array}$ & 208 \\
\hline $\begin{array}{l}8 \text { October- } \\
13 \text { November } 1969\end{array}$ & 635 & $21 \underset{8 \text { April }}{1970}$ & $29^{\mathrm{b}}$ \\
\hline
\end{tabular}

most active spawning period for the spring run.

Spring run rainbow trout were larger than those in the fall run. In the 1969 spring run they averaged $546 \mathrm{~mm}$ compared to $521 \mathrm{~mm}$ for the 1968 fall run. In this spring run the sex ratio was 2.1 females per male as compared with 2.2 in the fall run.

McConaughy Reservoir contains rainbow trout which originated from the spawning streams but did not return to spawn. This became evident during the early spring of 1967 and 1968 when sexually mature rainbow trout were captured and tagged along the dam and rocky shoreline areas of the reservoir. Ovaries of some of these females examined upon recapture later the same spring showed signs of egg absorption which indicated these trout apparently had not spawned or left the reservoir. All the tag returns by anglers during the next two years $(23 \%$ of the 89 rainbow tagged) came from the reservoir; none were from the spawning streams. These tagged fish were not of hatchery origin because all rainbow trout stocked in the drainage since 1963 were marked.

\section{Environmental Conditions}

The spawning streams are annually subjected to a variety of conditions. During the agricultural growing season (May through September) these spawning streams with a base flow of groundwater, are subjected to flooding, irrigation return water, and releases of water from the numerous canals in the intensively farmed North Platte Valley. Turbidity of the spawning streams is higher during this period than in winter. Water tem- peratures exceeding $24 \mathrm{C}$ for a short duration are common in many spawning streams during summer. In the best spawning area of Nine Mile Creek temperatures ranged between 12 and $21 \mathrm{C}$ in a $24-\mathrm{hr}$ period during the summer of 1967. Rainbow trout $50-100 \mathrm{~mm}$ long which have hatched during the previous winter and spring survive these summer conditions.

At the end of the irrigation season (October through April) the streams clear and stream flow becomes constant. Water temperatures during winter range between 5 and $10 \mathrm{C}$.

The spawning riffles available represent a divergence from the usual rainbow trout spawning habitat. In Nine Mile Creek the spawning riffles are composed of a hard compressed clay referred to as Brule clay. As the stream eroded the Brule clay formation, clay broke off in pieces approximately $25-100 \mathrm{~mm}$ in diameter. This clay has persisted because it is much more resistent to erosion than the other soils in the watershed.

Oxygen and temperature conditions restrict the coldwater habitat for rainbow trout in the reservoir during the summer only. Trout habitat began decreasing in June and continued until the most critical period which was sometime during the first three weeks in August. During August the coldwater trout habitat was restricted to a vertical depth of $3 \mathrm{~m}$ and 4,694 ha in 1969 and $7 \mathrm{~m}$ and 5,342 ha in 1970. Extreme critical conditions lasted approximately two weeks and then the amount of trout-supporting water began to increase. The wind, which is nearly always blowing, undoubtedly helps keep this reservoir suitable for rainbow trout survival during the summer. No known summer kill of trout has occurred in the reservoir.

\section{History}

The origin of the rainbow trout population remains uncertain. Other than stocking records practically no information concerning the rainbow trout population was recorded until the mid-fifties when biologists began inventorying the streams in the North Platte River drainage.

Rainbow trout were first stocked into the 
North Platte River drainage in Nebraska during 1911. Many of the present day spawning streams were stocked periodically from 1915 through 1967. It is not known if trout were present in the streams before the original stocking or if natural reproduction resulted from these early introductions. Periodical rainbow trout introductions were made directly into the reservoir during the 19471967 period.

During the mid-forties there were reports of large rainbow trout in some of the streams in the drainage. One of the best documented rainbow trout runs occurred in Ottar Creek, a small stream emptying directly into McConaughy Reservoir. In March 1948 the Nebraska State Rock Creek Hatchery and the Crawford National Fish Hatchery collected eggs from rainbow trout that migrated into this stream. At this time rainbow trout were present in this stream from December through April. These runs diminished during the 1950 's and have only recently been reestablished. By the late forties and early fifties frequent catches of large rainbow trout were reported from the present day spawning streams.

\section{Hatchery vs. Wild Trout}

An evaluation of the rainbow stocking program in the drainage was conducted for a 7-yr period. During the 1963-1967 period 32,548 hatchery reared rainbow trout stocked in the spawning streams and 7,595 wild rainbow trout captured in the spawning streams were finclipped when they were $102-203 \mathrm{~mm}$. Spawning runs from the reservoir were sampled to determine the contribution of these marked fish. During the recapture period (1963-1970) only 9 marked adult hatchery rainbow trout were examined as compared to 85 marked wild rainbow trout. Stocking of hatchery trout appeared to contribute very little to the spawning runs from the reservoir so this practice was terminated. The present management plan emphasizes habitat development and use of rainbow trout progeny from McConaughy Reservoir to develop spawning runs in additional streams within the drainage.

\section{DISCUSSION}

Although this rainbow population survives conditions in a setting unlike that of many other populations, the growth rate, especially during the first year of life in the streams, is rapid enough to cause a high percentage of 1-year-old smolts. The $92 \%$ 1-year-parr or stream life reported in this study is higher than in other spawning populations reported from inland lakes. Dodge and MacCrimmon (1970) and Greeley (1933) reported less than $10 \%$ of the downstream migrants were $1 \mathrm{yr}$ old. Kwain (1970) reported $38 \%$ and Stauffer (1972) reported $68 \%$ of the downstream migrants were rainbow trout with 1 yr of parr life.

It appears progeny from a fall spawning trout would have a survival advantage over progeny from a spring spawning trout in the drainage. The fry from the fall run begin showing up in the streams during midFebruary. These fish have from February until the irrigation season in mid-May to grow and adapt to the stream environment. In comparison the spring run fry become evident in the stream during the last part of April and have a relatively short time to adapt before the onset of the irrigation season and its influences. Although no distinction between fall and spring run juveniles were made in the spawning streams the spring run juveniles were several months younger so were probably the smallest individuals. This would undoubtedly contribute to a higher mortality upon migration into the reservoir. These two factors would certainly favor the perpetuation of the fall spawning type.

From either the mass stocking of rainbow trout in the Nebraska portion of the drainage or the presence of rainbow trout introductions somewhere higher in the North Platte River drainage, or a combination of both, has evolved a rainbow trout population that has taken advantage of the available environment and established itself to a point where it is now better adapted to the drainage than the hatchery product. This population is a prime example of the ability of rainbow trout to successfully adapt under a variety of environmental conditions. 


\section{ACKNOWLEDGMENTS}

The author is grateful to Jack L. Peterson and the rest of the Nebraska Game and Parks Commission biologists who assisted with field data. W. Harry Everhart and Robert E. Thomas reviewed the manuscript. This study was contributed to in part through the $\mathrm{Na}$ tional Marine Fisheries Service under Federal Aid Project 4-57-R.

\section{LITERATURE CITED}

Dodge, D. P., and H. R. MacCrimmon. 1970. Vital statistics of a population of Great Lakes rainbow trout (Salmo gairdneri) characterized by an extended spawning season. J. Fish. Res. Board Can. 27: 613-618.

Greeley, J. R. 1933. The growth rate of rainbow trout from some Michigan waters. Trans. Amer. Fish. Soc. 63: 361-378.

Hartman, W. L. 1957. Finger Lakes rainbowsA chronicle of their progress from egg to adult. N. Y. State Conserv. 11: 20-22.

- 1959. Biology and vital statistics of rainbow trout in the Finger Lakes Region, New York. N. Y. Fish Game J. 6: 121-177.

Kirkland, L., and M. Bowling. 1966. Preliminary observations on the establishment of a reservoir trout fishery. Proc. 20th Annu. Conf., Southeast. Ass. Game Fish Comm. 569 p.

KwaIN, Wen-Hwa. 1971. Life history of rainbow trout (Salmo gairdneri) in Batchawana Bay Eastern Lake Superior. J. Fish. Res. Board Can. 28: 771-777.

Madsen, M. L. 1973. An experimental electric barrier and trap for removing non-game fish from a reservoir tributary. Mimeo. Rep. Nebr. Game Parks Comm. 33 p.

McCarraier, D. B., M. L. Madsen, and R. E. Thomas. 1971. Ecology and fishery management of McConaughy Reservoir, p. 299-311. In Gordon E. Hall (ed.) Reservoir fisheries and limnology. Amer. Fish. Soc. Spec. Pub. No. 8., Washington.

RAYNER, J. H. 1941. The development of a management policy for the rainbow trout of the Finger Lakes. Ph.D. Thesis, Cornell U. 97 p.

Silapovalov, L., and A. C. Taft. 1954. The life histories of steelhead rainbow trout (Salmo gairdneri, Richardson) and silver salmon (Oncorhynchus kisutch) with special reference to Waddell Creek, California, and recommendations regarding their management. Calif. Dep. Fish Game. Fish Bul]. 98: 375 p.

Stauffer, T. M. 1972. Age, growth, and downstream migration of juvenile rainbow trout in a Lake Michigan tributary. Trans. Amer. Fish. Soc. 191: 18-28. 